\title{
How to Misuse Drugs
}

\author{
I.R. Edwards
}

Professor of Medicine, Department of Medicine, Harari Central Hospital, Salisbury, Rhodesia Address given at the Congress of the Rhodesia Nurses' Association, Salisbury, May 1978

\section{OPSOMMING}

Die meeste van ons leer tydens ons opleiding wat die werking en newe-effekte van medikamente is, maar baie min van ons word geleer hoe om medikamente te misbruik. Dit lyk egter of dit 'n kuns is wat verskillende lede van die mediese en verpleegberoep asook die algemene publiek deur herhaalde hantering verkry. Die doel van die referaat is om voorbeelde te gee van enkele maniere waarop medikamente misbruik word en misbruik kan word.

Daar bestaan skynbaar min twyfel daaroor dat die algemene sosiale klimaat in die beskaafde wêreld die gebruik van chemikalië̈ as 'n oplossing vir talle verskillende soorte probleme beskou, en dit moedig die gebruik by die hele bevolking aan. In die opsig is dit opmerklik dat dwelmslawe dit in hulle geskiedenis aangee dat hulle hulle ouers meer dikwels medikamente sien gebruik het (dikwels net 'n apsirien) as nie-verslaafde beheerdes.

Die moderne terapeutika het 'n groot verskeidenheid chemiese verbindings tot ons beskikking gestel wat 'n groot verskeidenheid siektes kan verlig. Ek meen dat die toenemende doeltreffendheid van dergelike samestellings 'n groter behoefte aan verantwoordelikheid en wysheid in hulle gebruik meebring.

\section{INTRODUCTION}

$\mathbf{M}$ OST of us, during our training, are taught about the actions of drugs and their side-effects. but very few of us are taught how to misuse drugs. However, this is an art that seems to be acquired through practice in handling drugs. by various members of the medical and nursing professions. as well as by the general population. The purpose of this paper is to demonstrate a few of the ways in which drugs can be, and are misused.

The drug industry is a very big business, financially, and Fig. 1 shows the approximate cost of developing a new drug. Fig. 2 shows some of the statistics relating to the development of a new drug. In particular, it is noteworthy how many compounds are tested; how long it takes; the enormous cost for some of the toxicity testing; and how much The Company may expect in return for all this development. At the bottom of Fig. 2, is the question of post-marketing surveillance, which will. cost an even greater amount of money, but which many licencing authorities feel is necessary to properly safeguard the public from unanticipated side-effects of powerful modern drugs. In misusing drugs, we can negate the hard work put into the development of the drug in order to make it safe

\section{INDICATIONS}

The misuse of drugs often starts with the prescription of a drug without valid reason. In two commonly prescribed groups of drugs there are many examples of this.

\section{"Antibiotic Promiscuity"}

Antibiotics are the most frequently prescribed drugs in general practice in the United Kingdom. Fig. 3 shows some published statistics about their use. It seems to me almost incredible that 38 per cent of dental patients receive antibiotics, that 62 per cent of patients in one survey showed no bacteriological evidence of infection; and a similar percentage either did not need the drugs, or received them incorrectly. I have two "black-lists" (Figs. 4 \& 5) which are medical and surgical indications in which antibiotics are frequently misused. Earache is a common symptom. and may well be due to a middle ear infection. If it is, then an antibiotic is clearly indicated. However, how many times is an antibiotic given in general practice without even looking in the patient's ear?

There is absolutely no need for systemic antibiotics for otitis externa, for instance. Even if the diagnosis is otitis media, penicillin or erythromycin are probably the only two antibiotics which need to be prescribed routinely. There is no 
Figure 1

Average cost per compound to Pharmaceutical Company of research and development

\begin{tabular}{lr}
\hline Development Step & Cost \$ \\
\hline Preclinical testing (chemical & \\
$\quad$ development, pharmacology & \\
$\quad$ screening, short- and long-term & 500000 \\
$\quad$ toxicology & 450000 \\
Phase I human trials & 750000 \\
Phase II human trials & 1400000 \\
Phase III human trials & 3100000 \\
Total & \\
\hline
\end{tabular}

Figure 2.

N.B.

1. Approx 10000 compounds -1 drug on market

2. Approx. 7 years for development (patent)

3. Approx. $\$ 35000$ for long-term animal toxicity

4. Approx. $\$ 1000-5000$ for a single small clinical trial

5. Approx. $\$ 50000-150000$ for major trials

6. $\$ 50000$ p.a. would be a good earner!

7. ? post-marketing surveillance

Figure 3 .

\section{ANTIBIOTIC PROMISCUITY}

163 million scripts in U.K.

$15-20 \%$ of all drugs (top drug in G.P.)

$38 \%$ dental patients receive them. (j. oral surg. 1976)

$62 \%$ patients showed no infection. (J.A.M.A. 1970)

$65 \%$ patients did not need them, or had a wrong dose.

(Am.J.Pharmacy 1972)

$5-30 \%$ incidence of adverse reactions

DIAGRAM 6

TIMING OF DOSE

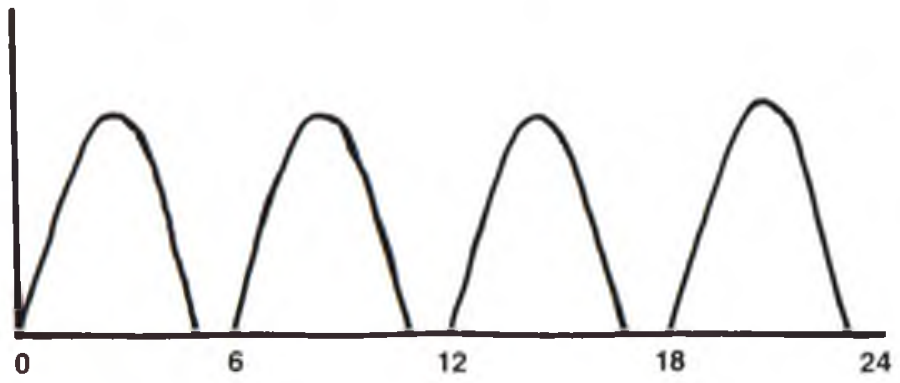

Figure 4.

\section{BLACK LIST I}

Earache

Sore throat

Cough

Diarrhoea

Dysuria

P.U.O.

Figure 5.

\section{BLACK LIST II}

Surgery

Post-operative pyrexia

Post-operative chest infection

Urinary catheter

Intubation

Infected infusion

\section{Diagram 7}

\section{DRUG DISTRIBUTION AFTER ORAL ADMINISTRATION OF A DRUG PREPARATION}
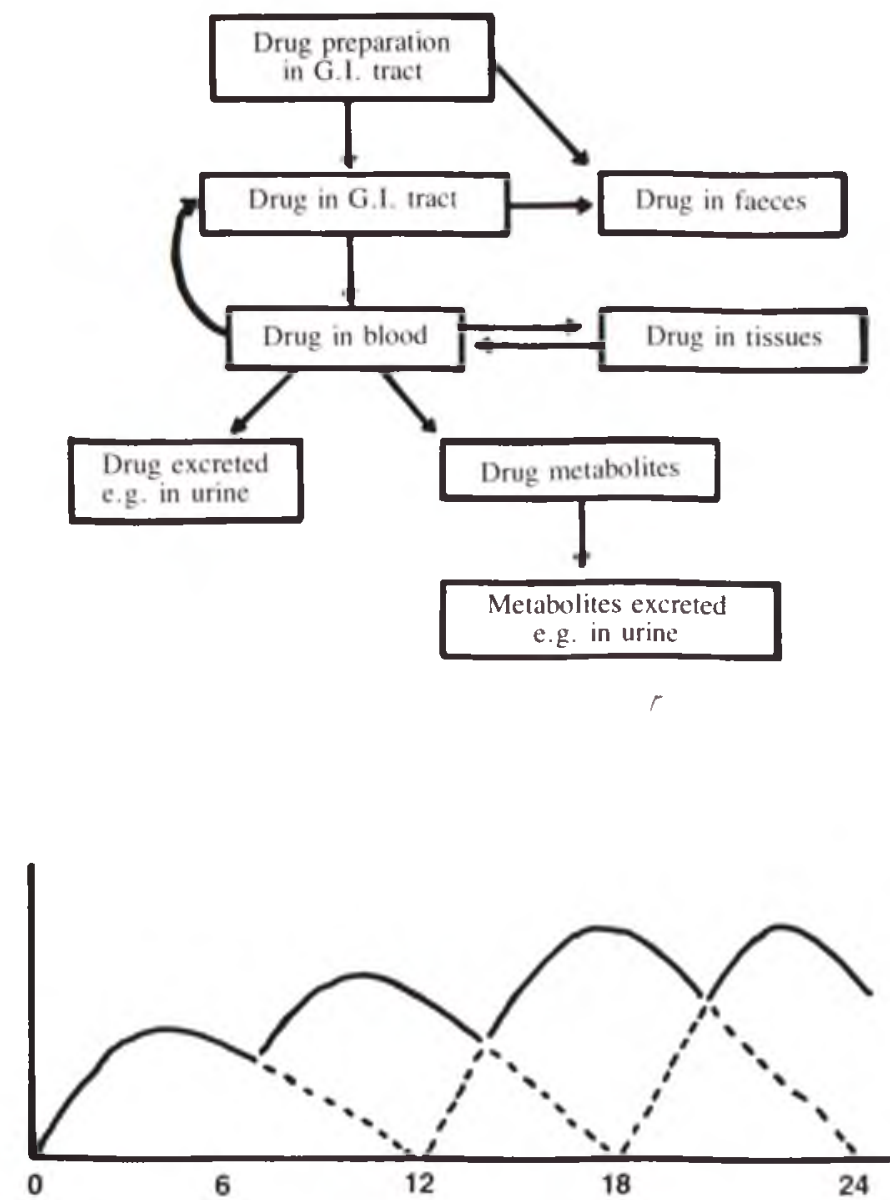
need to use broad-spectrum antibiotics such as cotrimoxazole and ampicillin.

Sore throat, too, is a common symptom, and again no-one argues with the use of antibiotics if this is of a streptococcal origin. Again, however, penicillin is the antibiotic of choice, unless the patient is penicillin-sensitive. (You must always remember to ask!) It is, however, totally wrong to give an antibiotic for a viral sore throat - and these, I would suggest, are the majority.

Cough may be symptomatic of many diseases, and it is totally inappropriate to use antibiotics without determining the etiology. I have even seen antibiotics given for a cough in a patient with left ventricular failure. It is true, however, that patients with chronic bronchitis may receive benefit from treatment with antibiotics when no clear causative organism can be cultured, but these patients are a special case.

Diarrhoea is often due to viral gastroenteritis, and even when bacillary, often does not need treatment with antibiotics in many cases. Such treatment will result in prolongation of the diarrhoea, due to alteration of intestinal flora, and indeed, antibiotics may be the original cause.

Dysuria again may be due to a variety of causes other than bacterial infection. It is quite wrong to treat dysuria without making an attempt to find the cause, and particularly, one must check if the upper urinary tract is involved.

Finally, pyrexia of unknown origin is a great temptation to use antibiotics without a bacteriological diagnosis. It is bad enough to use antibiotics unnecessarily, but in PUO it is quite possible to partially treat an infection, enough to make diagnosis impossible, but still allowing a bacterial endocarditis, for example. to continue to cause damage.

The surgical "black-list" includes post-operative pyrexia, which I view with the same misgivings as PUO - serious infection being masked by precipitate antibiotic use. Some surgeons regard an operation in itself as a reason for giving antibiotics, to prevent wound infection. My feeling is that all they are doing is to create resistant organisms in their unit resulting in a new class of wound infection, more difficult to treat.

Post-operative chest infections may well be bacterial, but I wonder how many of these can be avoided by good postoperative physiotherapy.

Antibiotics are often given routinely where a urinary catheter or endoctracheal tube is inserted. Again, I believe this merely creates an environment of resistant organisms and is an extremely short-sighted approach.

Infected infusion sites may necessitate antibiotics, but it has been frequently shown that care in initiating infusions may well avoid such complications. The routine changing of infusion sites every 36-48 hours is also helpful.

Antibiotics, then, are commonly used and misused drugs, and such misuse is helping the breed, selectively, the 'cheetahs' of the antibiotic world - the real fast resistant killers.

\section{Tranquillizers and Sedatives}

"The children are terrible. and you know mother has arthritis - she's 85 you know... This is a common general practice problem, which is often treated by giving tranquillizers. The patient who made this complaint was given diazepam, which she dutifully took, and was so sedated that she could no longer cope at all with the children and mother. The housework deteriorated and so did her marriage. Her husband, amongst other things, called her a "lazy slut". She returned to her general practitioner. who recognised that her sedation was probably the side-effect of diazepam, and took her off it, suggesting that she would probably "be alright now", but of course she was not, and because she could not get help from the medical profession, she found her way into drug addiction, and began to take amphetamines. I would suggest that this is a gross misuse of tranquillizers. Certainly they are useful in anxiety states, but only as an adjunct to some kind of supportive psychotherapy, or practical support, such as help in the house. Similarly, the patient who comes and asks for "the usual sleeping tablets" - again, must have been badly mismanaged. Most patients do not really suffer from chronic insomnia, and whilst it may be justifiable to give a short course of sleeping tablets. I believe it is wrong to perpetuate it, particularly since there is an increased incidence of suicide from overdose of such medications. In the younger age group, it is striking how often the overdose consists of mother's sleeping tablets.

On a wider basis, I believe that the injudicious use of tranquillizers and sedatives has eroded the patient-doctor relationship. It reduces the dialogue between the patient and the doctor, and I believe, vastly increases the likelihood of misdiagnosis and, therefore, maltreatment of mental disorder; and it leads to the idea that some kind of chemical is an answer to all life"s ills.

These then, are some examples of drugs given for the wrong indication.

\section{ADMINISTRATION}

Having decided that a drug is properly indicated, the next step is to administer it accurately. Fig. 6 demonstrates two problems in the timing of dosing. The upper diagram shows the blood level curve of a short-acting drug, given at $0 ; 6 ; 12$; and 18 hours. Obviously the blood level rises and falls, but it is noteworthy that the level falls to zero before the next dose is given. Clearly, this means that the drug action is going to be intermittent, and the doses should be administered at more frequent intervals. An example of this, would be heparin, which, if given six-hourly, does not provide continuous satisfactory anticoagulation. A four-hourly regime, or wherever possible, and continuous intravenous infusion is preferable.

The lower diagram demonstrates a drug with a long duration of action, and it can be seen over the first eighteen hours, that there is a build-up of blood levels, as each dose is given prior to the decline of the previous dose. Stabilization eventually occurs, but care must be taken that the build-up of blood levels does not enter the toxic range.

Drugs like this are often given as a large loading dose to produce a high initial level fairly quickly, and subsequent, smaller doses, looking very carefully for the toxic build-up mentioned.

An example of this kind of drug would be digoxin.

DRUG/DRUG AND DRUG/PATIENT INTERACTIONS

The kinetics of a drug given to a normal person, described in the previous section, can be altered very considerably by the presence of other drugs, or in the presence of certain diseases.

Diagram 7 shows what happens to a drug given orally. It can be seen that drugs can be considered acting within the body under the headings: Absorption; Distribution; Metabolism; Excretion; and under each of these headings lack of thought or knowledge can lead to problems. 


\begin{abstract}
Absorption
Absorption is controlled by many factors, such as gastrointestinal motility, gastro-intestinal blood-flow, and the presence of diseases of the G.I. tract. As an example of drug interaction, prior to absorption; tetracycline is usually fairly well absorbed, but the presence of metallic ions such as magnesium and calcium, almost entirely prevent this absorption, rendering the drug absolutely useless.
\end{abstract}

It is. therefore, very necessary to avoid giving tetracycline in the presence of milk, or antacid preparations.

\section{Distribution}

Highly ionized drugs find difficulty in crossing the lipid bi-layer membranes within the body, thus they tend to be poorly absorbed, they penetrate some tissues poorly, they have difficulty in crossing the 'blood-brain' barrier into the cerebral substance. and they may not be excreted easily by the kidney. Penicillin is moderately well ionized, and normally would not penetrate into the brain. However, meningit is impairs the 'blood-brain' barrier, and allows penicillin to be a useful antibiotic for this disease. This does not. however, mean that other cerebral infections could be treated in the same way, and noteworthy is cerebral abscess or the use of penicillin as a prophylaxis in CSF rhinorrhoea, in which penicillin is likely to be ineffective at doses given for meningitis, because of lack of penetration. even if the organism is sensitive

\section{Metabolism}

Many drugs are metabolised in the liver. and this metabolism depends largely on the activity of the liver microsomal enzyme systems. There are certain drugs that activate these enzyme systems, and will, therefore alter the metabolism of other drugs. An example of this lies in anticoagulation with warfarin, which is metabolised in the liver. Many patients are stabilised whilst in hospital, and during this time. they may also be given barbiturate sedatives, which induce the liver enzymes. The result of this, of course, is that more warfarin has to be given, since it is being metabolised more rapidly than normal. When the patient leaves hospital, however, if the barbiturates are stopped, the patient will be receiving too much warfarin for this new situation, since the liver enzymes are no longer stimulated by barbiturates. The result of this, of course, can be haemorrhage, in some instances catastrophic.

\section{Excretion}

Drugs that on the whole are not metabolised are often excreted by the kidney, and some of these drugs are, indeed. toxic to the kidney as well. An example of this is, of course, the aminoglycocide antibiotics such as gentamycin. Genlamycin is excreted by the kidney, and the levels rise in renal failure. This gives rise to a "vicious circle" situation, whereby the gentamycin is poorly excreted, giving rise to high blood levels. The higher the blood level, the more likely there is to be renal damage due to the gentamycin and with further renal damage, of course, the level of gentamycin in the blood rises again, and so on. Thus we need to be aware of these facets when handing drugs to patients.

\section{Prescribing}

Finally, having taken all these factors into account, we have to write a prescription, but I must emphasise here that the medication and the instructions must be clearly written down and also communicated to the patient. There is no point in taking great care over choosing a drug for a given circumstance, and then find that the patient does not take it in the way in which it could be most effective.

\section{DRUG ABUSE BY INDIVIDUALS}

From what I have said, in the foregoing section, drugs must be handled responsibly and with considerable forethought by medical and nursing staff. After a prescription has been written, it rests with the patient what he should do with the drugs. Many patients do not take the drugs as directed and, notorious in this respect, is the patient who takes antibiotics till he feels better, and then stops, only to suffer a relapse at a later date, because he did not take a complete course. More serious of course, is the abuse of hypnotic and sedative drugs, resulting sometimes in addic-. tion. This, thankfully, is a rare problem, but whilst the drug addict on so-called hard drugs does not represent a very large problem in terms of numbers, they are worth consideration, in terms of the amount of time which their management consumes. They are also important because at least some of them are addicts because of our therapeutic misuse of drugs, and our general mismanagement of the patient, as I have outlined above.

Traditionally, alcohol has been widely used to solve many psycho-social problems! But we must remain aware that alcoholism is the common form of chemical addiction in most civilized countries, resulting in damage to individual health, with the development of cirrhosis of the liver, and many social problems. due to the financial difficulties of obtaining enough alcohol and the irresponsible behaviour of the alcoholic.

A little less dramatic. but very serious, is the addiction to cigarette smoking. We all know of the damage that cigarettes can do to the lungs and the cardiovascular system. I think it is our responsibility to make sure that patients are aware of the hazards they undertake, but at least these hazards largely affect the individual, though there is increasing evidence that one inhales a significant dose of nicotine whilst being in the same room as a smoker.

\section{CONCLUSION}

There seems little doubt that the general social climate pertaining in the civilized world involves the use of chemicals as a solution to many different kinds of problem, and this encourages the use and abuse of drugs by the population as a whole. In this respect, it is noteworthy that drug addicts give a history of seeing their parents use drugs (often only an aspirin for headache) more frequently than non-addict controls.

Modern therapeutics has given us a wide variety of chemical compounds which can alleviate a wide variety of illnesses. Increasing efficacy of such compounds, I believe, brings with it an increased need for responsibility and wisdom in their use.

In this paper, I hope I have succeeded in giving some examples where pitfalls may occur in our therapeutic endeavours. 